\title{
PENERAPAN MODEL COBB-DOUGLAS DALAM PEMODELAN FUNGSI PRODUKSI DAN EVALUASI KINERJA FAKTOR PRODUKSI PADI DI INDONESIA TAHUN 2016
} (Application of the Cobb-Douglas Model in Production Function Modelling and Performance
Evaluation of Rice Production in Indonesia in 2016)

\author{
Lutfi Hamdani Sutikno \\ Politeknik Statistika STIS \\ Jalan Otto Iskandardinata 64C, Jakarta Timur \\ E-mail: 211709794@stis.ac.id
}

\begin{abstract}
ABSTRAK
Indonesia merupakan negara produsen padi terbesar ketiga di dunia pada tahun 2016, dengan produksi padi sebesar 74.5 juta ton (FAO, 2017). Namun capaian produksi padi Indonesia tersebut belum ditunjang oleh produktivitas yang memadai. Produktivitas padi Indonesia masih relatif rendah yakni sebesar 5,18 ton per hektare, lebih rendah jika dibandingkan Bangladesh dan Vietnam yang memiliki nilai produksi padi lebih sedikit. Ketidakoptimalan produktivitas padi dapat dipengaruhi oleh berbagai hal, salah satunya kinerja faktor produksi yang secara langsung menunjang nilai produksi padi. Faktor produksi tersebut yakni luas lahan sawah $\left(X_{1}\right)$, jumlah petani $\left(X_{2}\right)$, serta asupan gizi bagi tanaman berupa pupuk organik dan anorganik bersubsidi $\left(\mathrm{X}_{3}\right)$. Penerapan model Cobb-Douglas dalam pemodelan fungsi produksi padi di Indonesia tahun 2016 diselesaikan dengan transformasi Regresi Linier Berganda (RLB) yang menghasilkan model regresi yang fit dan proper. Terbentuk fungsi produksi padi $\hat{Y}=0,00025 \times 2,938 X 1 \times 2,664 X 2 \times 1,085 X 3$ dimana variabel realisasi penyaluran pupuk organik dan anorganik bersubsidi $\left(X_{3}\right)$ memiliki nilai elastisitas terendah di antara ketiga variabel independen dan secara statistik tidak signifikan mempengaruhi perubahan nilai produksi padi $(\mathrm{Y})$. Kinerja variabel realisasi penyaluran pupuk organik dan anorganik bersubsidi $\left(\mathrm{X}_{3}\right)$ yang secara statistik tidak signifikan mempengaruhi perubahan nilai produksi padi $(Y)$ disebabkan oleh beberapa hal. Yang pertama, adanya keterlambatan penerimaan pupuk bersubsidi di tingkat petani akibat panjangnya mata rantai perencanaan dan penyaluran; kedua, mekanisme penetapan harga penjualan pokok (HPP) pupuk bersubsidi membuka celah korupsi dan mendorong inefisiensi di tingkat produsen; dan ketiga, adanya gap antara kebutuhan di tingkat petani dan realisasi subsidi oleh Kementerian Pertanian.
\end{abstract}

Kata kunci: Cobb-Douglas, fungsi produksi padi, regresi linier berganda, subsidi pupuk, Indonesia

\section{ABSTRACT}

Indonesia was the third largest rice producing country in the world in 2016, with rice production of 74.5 million tonnes (FAO, 2017). However, the achievements of Indonesia's rice production have not been supported by adequate productivity. Indonesia's rice productivity is still relatively low, namely 5.18 tons per hectare, lower than Bangladesh and Vietnam, which have less rice production value. The failure to optimize rice productivity can be affected by various factors, one of which is the performance of production factors which directly support the value of rice production. The production factors are rice field area $\left(X_{1}\right)$, number of farmers $\left(X_{2}\right)$, and nutritional intake for plants in the form of subsidized organic and inorganic fertilizers $\left(X_{3}\right)$. The application of the Cobb-Douglas model in modeling the rice production function in Indonesia in 2016 was completed by the transformation of Multiple Linear Regression which produced a fit and proper regression model. A rice production function was formed $\hat{Y}=0,00025 \times 2,938 X 1 \times 2,664 X 2 \times$ $1,085 X 3$ where the realization of subsidized organic and inorganic fertilizers $\left(X_{3}\right)$ had the lowest elasticity value among the three independent variables and did not statistically significantly affect changes in the value of rice production $(Y)$. The variable performance of the distribution of subsidized organic and inorganic fertilizers (X3) which statistically did not significantly affect the change in the value of rice production ( $Y$ ) was caused by several reasons. First, there is a delay in receiving subsidized fertilizers at the farm level due to the long chain of planning and distribution; second, the mechanism for setting the price of subsidized fertilizer opens up gaps in corruption and encourages inefficiency at the producer level; and third, there is a gap between the needs at the farm level and the realization of subsidies by the Ministry of Agriculture.

Keywords: Cobb-Douglas, rice production function, multiple linear regression, fertilizer subsidies, Indonesia 


\section{PENDAHULUAN}

Indonesia dikenal sebagai negara agraris yang dikaruniai kekayaan alam yang melimpah dengan keanekaragaman hayati yang sangat besar (mega biodiversity). Julukan negara agraris pun disematkan karena sebagian besar penduduk Indonesia memiliki mata pencaharian sebagai petani atau bercocok tanam. Sebagai negara agraris, pertanian di Indonesia menghasilkan berbagai macam komoditas, salah satunya yang terbesar adalah tanaman padi (Oryza Sativa L.). Bagi sebagian besar penduduk Indonesia, padi yang akan diproses menjadi beras merupakan makanan pokok yang paling banyak dikonsumsi.

Merujuk pada Rencana Pembangunan Jangka Panjang dan Menengah Nasional (RPJMN) 20152019, pengelolaan pangan menjadi isu utama dalam ketahanan ekonomi salah satunya dengan peningkatan capaian produksi berbagai komoditas strategis termasuk beras. Berdasarkan data Food and Agriculture Organization (FAO), Indonesia merupakan negara produsen padi terbesar ketiga di dunia pada tahun 2016, dengan produksi padi sebesar 74.5 juta ton.

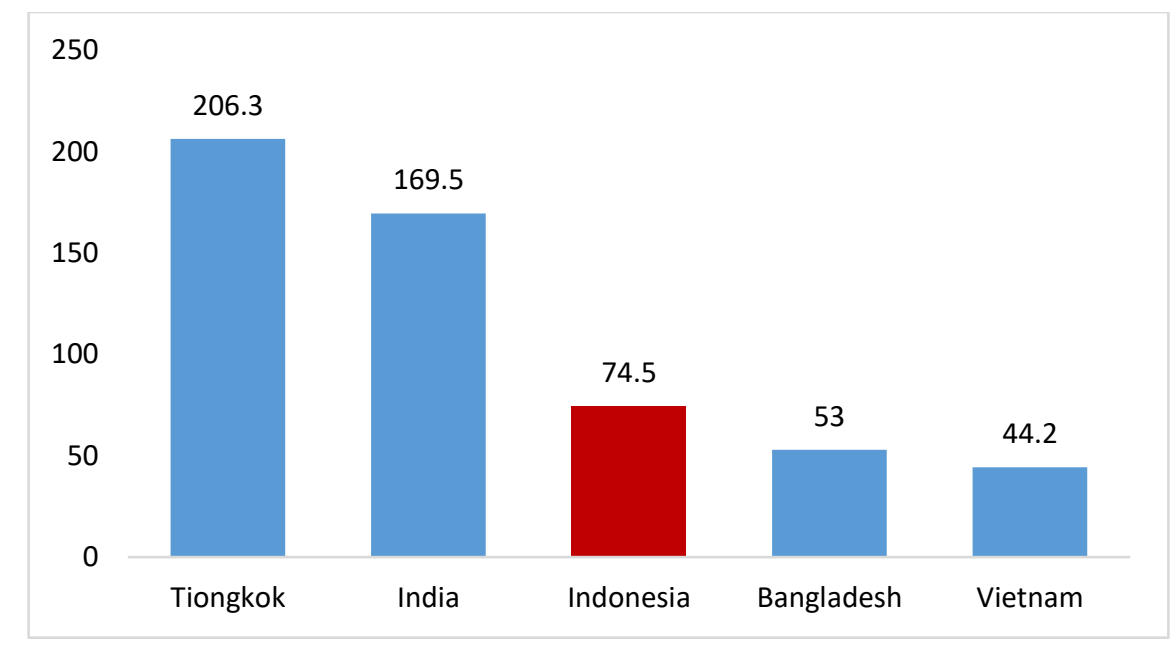

Sumber: FAO, diolah

Grafik 1. Negara Produsen Padi Terbesar Tahun 2016 (juta ton)

Namun capaian produksi padi Indonesia pada tahun 2016 tersebut belum ditunjang oleh produktivitas yang memadai. Jika dibandingkan dengan kelima negara produsen padi terbesar di dunia tersebut, produktivitas padi Indonesia masih relatif rendah yakni sebesar 5,18 ton per hektare. Masih lebih rendah jika dibandingkan Bangladesh dan Vietnam yang memiliki nilai produksi padi lebih sedikit.

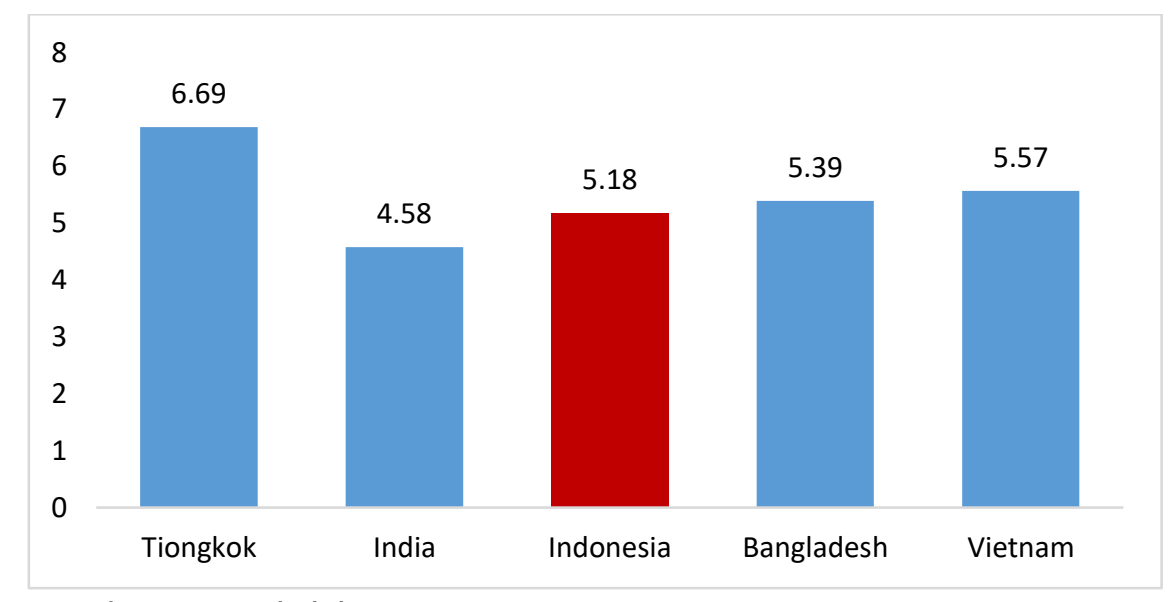

Sumber: FAO, diolah

Grafik 2. Produktivitas Produsen Padi Tahun 2016 (ton/hektare)

Sebagai komoditas pangan yang strategis, nilai produktivitas dan capaian produksi padi harus stabil dan memadai untuk memenuhi konsumsi dalam negeri sebab jumlah penduduk Indonesia dari tahun ke tahun terus mengalami peningkatan. Berdasarkan data Badan Pusat Statistik (BPS) 
yang diperoleh melalui Sensus Penduduk 2010, jumlah penduduk Indonesia mencapai 237.556.368 jiwa dengan laju pertumbuhan penduduk sebesar 1,49 persen per tahun. Pertumbuhan penduduk Indonesia yang relatif tinggi juga diikuti dengan peningkatan konsumsi beras per kapita (Susenas, 2016).

Ketidakoptimalan produktivitas padi dapat dipengaruhi oleh berbagai hal, salah satunya kinerja faktor produksi yang secara langsung menunjang nilai produksi padi. Faktor produksi tersebut yakni luas lahan sawah, jumlah petani, serta asupan gizi bagi tanaman berupa pupuk organik dan anorganik yang dalam hal ini berupa subsidi dari Pemerintah dengan asumsi pupuk organik dan anorganik yang digunakan petani padi hanya pupuk bersubsidi. Untuk mengevaluasi kinerja faktor produksi terhadap nilai produksi padi, dapat dilakukan dengan mengetahui tingkat signifikansi dan elastisitas faktor produksi. Penelitian ini mengaplikasikan model matematis CobbDouglas untuk memodelkan fungsi produksi padi sekaligus mengevaluasi kinerja faktor produksi padi di Indonesia tahun 2016.

\section{METODE}

Variabel yang digunakan dalam penelitian ini antara lain produksi padi (ton), rata-rata luas lahan sawah yang dikuasai rumah tangga usaha pertanian (hektare), jumlah petani (jiwa), dan realisasi penyaluran pupuk organik dan anorganik bersubsidi (ton). Data yang digunakan adalah data sekunder yang bersumber dari Badan Pusat Statistik dan Kementerian Pertanian. Periode data adalah tahun 2016. Populasinya adalah provinsi-provinsi di Indonesia. Metode analisis yang digunakan adalah analisis Regresi Linier Berganda untuk mengidentifikasi faktor-faktor yang berpengaruh secara signifikan terhadap produksi padi di Indonesia pada tahun 2016 dengan menggunakan model fungsi produksi Cobb-Douglas.

$$
\begin{aligned}
& \mathrm{Q}=A L^{\alpha} K^{\beta} \\
& \ln \hat{Y}=\ln \beta_{0}+\beta_{1} \ln X_{1}+\beta_{2} \ln X_{2}+\cdots+\beta_{n} \ln X_{n} \ldots \text {. (2) }
\end{aligned}
$$

dimana:

$\mathrm{Q} \quad=$ Output

$\mathrm{L} \quad=$ Tenaga kerja/labour

$\mathrm{K}=$ Modal/capital

$\mathrm{a}, \beta=$ Elastisitas

$\mathrm{Y} \quad=$ Produksi padi (ton)

$\beta_{0}=$ Konstanta

$\beta_{i}=$ Elastisitas produksi faktor produksi padi ke-i $(\mathrm{i}=1,2,3)$

$\mathrm{X}_{1}=$ Rata-rata luas lahan sawah yang dikuasai rumah tangga usaha pertanian $\left(\mathrm{m}^{2}\right)$

$\mathrm{X}_{2}=$ Jumlah petani (jiwa)

$\mathrm{X}_{3}=$ Realisasi penyaluran pupuk organik dan anorganik bersubsidi (ton)

\section{HASIL DAN PEMBAHASAN}

Penerapan model Cobb-Douglas dalam pemodelan fungsi produksi padi di Indonesia tahun 2016 diselesaikan dengan transformasi Regresi Linier Berganda (RLB). Pemodelan fungsi produksi padi dengan pendekatan model matematis Cobb-Douglas yang bersifat multiplikatif dinilai sesuai karena produksi tanaman padi (variabel dependen) akan bernilai nol jika salah satu dari ketiga faktor produksinya (variabel independen) bernilai nol. Hal ini sangat relevan dalam penelitian empiris mengingat tidak akan ada produksi padi jika tidak terdapat lahan sawah yang ditanami padi, petani padi, dan pupuk organik dan anorganik yang menunjang pertumbuhan tanaman padi dalam hal ini pupuk bersubsidi dengan asumsi petani padi tidak menggunakan pupuk organik dan anorganik non subsidi, sebab penelitian ini hendak mengevaluasi kinerja faktor produksi padi terhadap nilai produksinya.

Transformasi Regresi Linier Berganda untuk membentuk fungsi produksi Cobb-Douglass menghasilkan model sebagai berikut.

Tabel 1. Pemodelan Fungsi Produksi Padi dengan Transformasi RLB 


\begin{tabular}{|c|c|c|c|c|}
\hline & Coefficient & Std. Error & t statistics & Sig \\
\hline Constant & $-8,39737$ & 1,72332 & $-4,873$ & $3,34 \mathrm{e}-05$ \\
\hline $\operatorname{In} \mathrm{X} 1$ & 1,07757 & 0,14287 & 7,542 & $2,08 \mathrm{e}-08$ \\
\hline $\operatorname{In} \mathrm{X} 2$ & 0,97977 & 0,18061 & 5,425 & $7,02 \mathrm{e}-06$ \\
\hline $\ln \mathrm{X} 3$ & 0,08114 & 0,12057 & 0,673 & 0,506 \\
\hline
\end{tabular}

Sumber: Peneliti, diolah

Kemudian dilakukan pengujian asumsi klasik Regresi Linier Berganda yang meliputi uji normalitas, uji non autokorelasi, uji homoskedastisitas, dan pengecekan pelanggaran asumsi multikolinearitas. Berdasarkan pengujian yang dilakukan, diperoleh hasil sebagai berikut.

1. Uji Normalitas (Saphiro-Wilk test)

- $\mathrm{H}_{0}: \varepsilon_{i} \sim N\left(\mu, \sigma^{2}\right) \rightarrow$ residual model berdistribusi normal

- $\mathrm{H}_{1}$ : residual model tidak berdistribusi normal

- $a=0.05$

- Keputusan : $p$-value $=0.06588>\mathrm{a}$ (gagal tolak $\mathrm{H} 0)$

- Kesimpulan : Dengan tingkat signifikansi 5\%, dapat ditunjukkan bahwa residual model berdistribusi normal

2. Uji Non Autokorelasi (Durbin-Watson test)

- $\mathrm{H}_{0}: E\left(\varepsilon_{i} \varepsilon_{j}\right)=0 \rightarrow$ tidak terdapat masalah autokorelasi

- $\mathrm{H}_{1}: E\left(\varepsilon_{i} \varepsilon_{j}\right) \neq 0 \rightarrow$ terdapat masalah autokorelasi

- $\mathrm{a}=0.05$

- Keputusan : $p$-value $=0.1644>$ a (gagal tolak H0)

- Kesimpulan : Dengan tingkat signifikansi 5\%, dapat ditunjukkan bahwa tidak terdapat masalah autokorelasi pada model.

3. Uji Homoskedastisitas (Breusch-Pagan test)

- $\mathrm{H}_{0}: E\left(\varepsilon_{i}^{2} \mid \mu\right)=\sigma_{i}^{2}=\sigma^{2} \rightarrow$ model homoskedastis

- $\mathrm{H}_{1}: E\left(\varepsilon_{i}^{2} \mid \mu\right)=\sigma_{i}^{2} \neq \sigma^{2} \rightarrow$ model heteroskedastis

- $\mathrm{a}=0.05$

- Keputusan : $p$-value $=0.059594>$ a (gagal tolak H0)

- Kesimpulan : Dengan tingkat signifikansi 5\%, dapat ditunjukkan bahwa tidak terdapat masalah heteroskedastisitas pada model.

4. Pengecekan Pelanggaran Asumsi Multikolinearitas

- Matriks Korelasi

Tabel 2. Matriks Korelasi Variabel Independen

\begin{tabular}{|c|c|c|c|}
\hline & $\mathrm{X}_{1}$ & $\mathrm{X}_{2}$ & $\mathrm{X}_{3}$ \\
\hline $\mathrm{X}_{1}$ & 1,0000 & 0,5468 & 0,7284 \\
\hline $\mathrm{X}_{2}$ & 0,5468 & 1,0000 & 0,6087 \\
\hline $\mathrm{X}_{3}$ & 0,7284 & 0,6087 & 1,0000 \\
\hline
\end{tabular}

Sumber: Peneliti, diolah 
- Indikasi Nilai VIF

Tabel 3. Nilai VIF Variabel Independen

\begin{tabular}{|c|c|c|}
\hline \multicolumn{3}{|c|}{ VIF } \\
\hline $\mathrm{X}_{1}$ & $\mathrm{X}_{2}$ & $\mathrm{X}_{3}$ \\
\hline 2,5435 & 6,8503 & 8,2326 \\
\hline
\end{tabular}

Sumber: Peneliti, diolah

- Kesimpulan : Berdasarkan matriks korelasi dan nilai VIF, terindikasi tidak terdapat masalah multikolinearitas pada model.

Seluruh pengujian asumsi klasik Regresi Linier Berganda menunjukkan bahwa tidak terjadi pelanggaran asumsi dalam model sehingga dapat dikatakan model yang dihasilkan telah fit dan proper. Setelah dilakukan pengujian asumsi klasik, dilakukan pembentukan fungsi produksi dengan model Cobb-Douglas. Berdasarkan model hasil transformasi Regresi Linier Berganda pada Tabel 1, diperoleh model fungsi produksi padi sebagai berikut.

$$
\begin{gathered}
\ln \hat{Y}=-8,39737+1,07757 \ln X 1+0,97977 \ln X 2+0,08114 \ln X 3 \text {, maka: } \\
e^{\ln \hat{Y}}=e^{-8,39737} \times e^{1,07757 \ln X 1} \times e^{0,97977 \ln X 2} \times e^{0,08114 \ln X 3}
\end{gathered}
$$

Sehingga model Cobb Douglas yang dihasilkan adalah:

$$
\hat{Y}=0,00025 \times 2,938 X 1 \times 2,664 X 2 \times 1,085 X 3
$$

dimana parameter-parameter $\beta$ (elastisitas) yang dihasilkan yaitu:

$\beta_{1}=1,07757 ;$

$\beta_{2}=0,97977 ;$ dan

$\beta_{3}=0,08114$.

Selain membentuk fungsi produksi padi, informasi pada Tabel 1 juga menunjukkan bahwa dari ketiga variabel faktor produksi yang dilibatkan dalam model, secara statistik hanya variabel realisasi penyaluran pupuk organik dan anorganik bersubsidi $\left(X_{3}\right)$ yang tidak signifikan dalam model. Fakta tersebut juga didukung oleh nilai elastisitas variabel $X_{3}$ yang sangat kecil dibandingkan nilai elastisitas variabel lainnya. Hal ini menunjukkan bahwa perubahan nilai realisasi penyaluran pupuk organik dan anorganik bersubsidi $\left(X_{3}\right)$ tidak signifikan mempengaruhi perubahan nilai produksi padi di Indonesia tahun 2016.

Temuan tersebut tentu menimbulkan tanda tanya. Sebab idealnya realisasi penyaluran pupuk organik dan anorganik bersubsidi $\left(\mathrm{X}_{3}\right)$ dari Pemerintah akan signifikan meningkatkan produksi padi karena sifat pupuk yang bekerja sebagai katalisator dalam pertumbuhan tanaman padi. Sehingga tanaman padi tidak akan terus bertumbuh tanpa pemberian pupuk (Ihsan, 2012).

Kinerja variabel realisasi penyaluran pupuk organik dan anorganik bersubsidi $\left(X_{3}\right)$ yang tidak signifikan mempengaruhi perubahan nilai produksi padi di Indonesia disebabkan oleh beberapa hal. Yang pertama, keterlambatan penerimaan pupuk bersubsidi di tingkat petani akibat panjangnya mata rantai perencanaan dan penyaluran. Mekanisme perencanaan dan penyaluran pupuk bersubsidi sebagai berikut. 


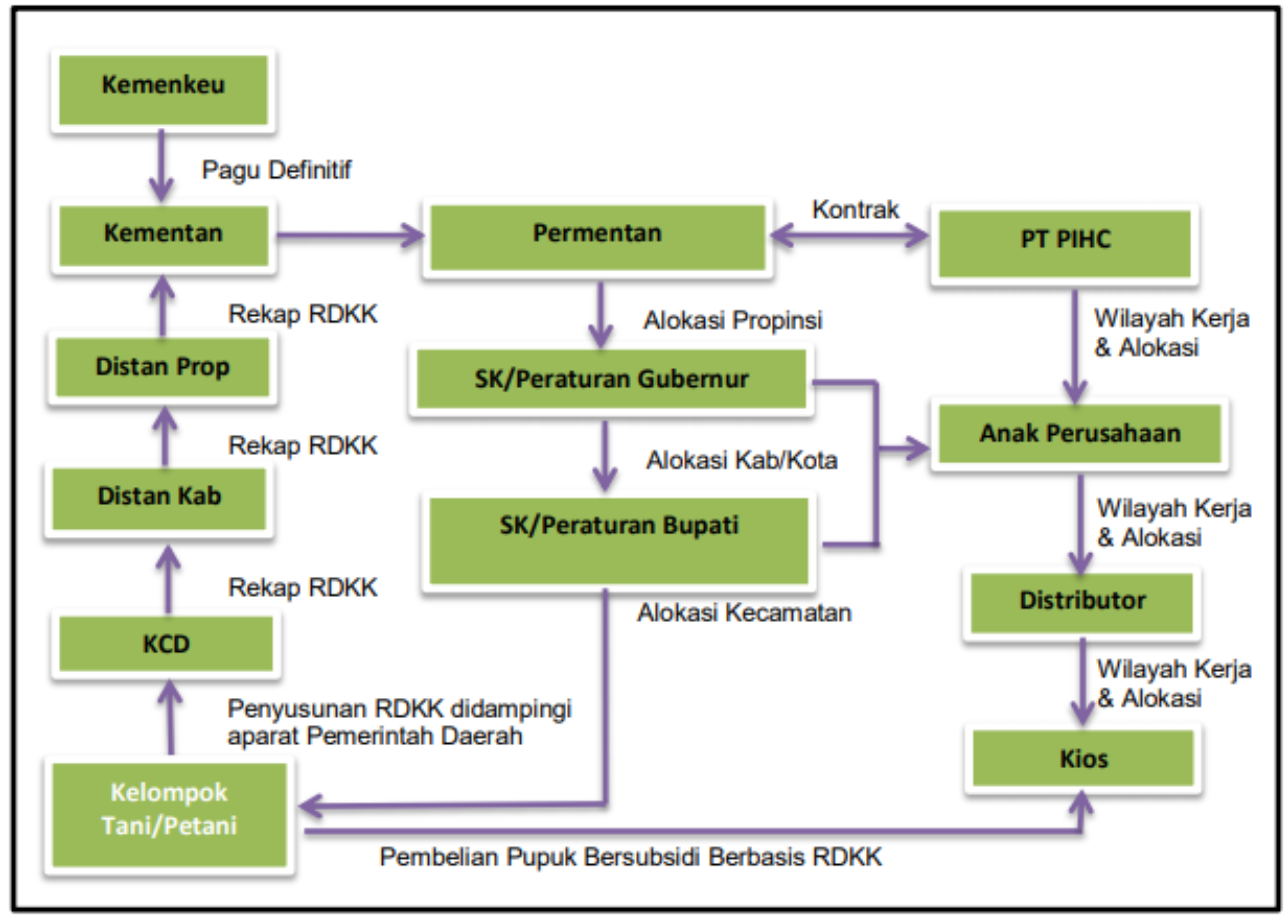

Sumber: KPK

Gambar 1. Alur Perencanaan dan Penyaluran Pupuk Bersubsidi

Yang kedua, mekanisme penetapan harga penjualan pokok (HPP) pupuk bersubsidi membuka celah korupsi dan mendorong inefisiensi di tingkat produsen. Dalam praktiknya, HPP terbagi menjadi dua, yakni HPP awal dan HPP audited. HPP awal ditetapkan oleh Menteri Pertanian. HPP awal dipergunakan sebagai acuan bagi pemerintah di tahun berjalan untuk membayar tagihan subsidi dari produsen pupuk. Setelah akhir tahun anggaran, Badan Pemeriksa Keuangan melakukan evaluasi guna menghitung riil HPP di tiap produsen pupuk bersubsidi. HPP hasil audited selanjutnya menjadi acuan untuk menilai adanya kekurangan atau kelebihan bayar kepada produsen pupuk. Penetapan HPP melalui pola tersebut membuka celah transaksional. Peluang transaksional kental muncul saat proses penilaian riil HPP, utamanya saat menentukan komponen biaya produksi yang layak masuk sebagai bagian penyusun HPP. Perbandingan nilai HPP Pemerintah dan HPP hasil audit BPK sebagai berikut.

Tabel 4. Perbandingan Nilai HPP Pemerintah dan HPP Audited BPK (Rupiah)

\begin{tabular}{|c|c|c|c|c|c|c|c|}
\hline \multirow[t]{2}{*}{$\begin{array}{l}\text { JENIS } \\
\text { PUPUK }\end{array}$} & \multicolumn{3}{|c|}{ 2013* } & \multicolumn{2}{|c|}{2014} & \multicolumn{2}{|c|}{$\begin{array}{c}201 \\
5\end{array}$} \\
\hline & \multicolumn{2}{|c|}{ HPP Awal } & $\begin{array}{c}\text { HPP } \\
\text { Audite } \\
\text { d }\end{array}$ & $\begin{array}{r}\text { HPP } \\
\text { Awal }\end{array}$ & $\begin{array}{c}\text { HPP } \\
\text { Audite } \\
\text { d }\end{array}$ & $\begin{array}{l}\text { HPP } \\
\text { Awal }\end{array}$ & $\begin{array}{c}\text { HPP } \\
\text { Audited }\end{array}$ \\
\hline \multicolumn{8}{|l|}{ UREA } \\
\hline Pusri Palembang & $\begin{array}{r}2.605 .0 \\
57 \\
\end{array}$ & 2.797 .739 & $\begin{array}{r}3.487 .18 \\
0 \\
\end{array}$ & $\begin{array}{r}2.797 .7 \\
39 \\
\end{array}$ & $\begin{array}{l}4.277 .12 \\
7\end{array}$ & $\begin{array}{r}4.181 .7 \\
89 \\
\end{array}$ & 4.938 .552 \\
\hline Pupuk Kaltim & $\begin{array}{r}3.287 .3 \\
40 \\
\end{array}$ & 3.784 .072 & $\begin{array}{r}3.866 .07 \\
7 \\
\end{array}$ & $\begin{array}{r}3.784 .0 \\
72 \\
\end{array}$ & $\begin{array}{l}4.077 .30 \\
3\end{array}$ & $\begin{array}{r}4.304 .8 \\
18 \\
\end{array}$ & 4.217 .729 \\
\hline Pupuk Kujang & $\begin{array}{r}2.688 .2 \\
88 \\
\end{array}$ & 3.224 .724 & $\begin{array}{r}3.446 .36 \\
6 \\
\end{array}$ & $\begin{array}{r}3.224 .7 \\
24 \\
\end{array}$ & $\begin{array}{l}4.205 .35 \\
5\end{array}$ & $\begin{array}{r}4.289 .5 \\
58 \\
\end{array}$ & 4.825 .916 \\
\hline Petrokimia Gresik & $\begin{array}{r}3.514 .8 \\
06\end{array}$ & 4.231 .283 & $\begin{array}{r}4.217 .00 \\
9\end{array}$ & $\begin{array}{r}4.231 .2 \\
83\end{array}$ & $\begin{array}{l}4.721 .67 \\
4\end{array}$ & $\begin{array}{r}4.596 .6 \\
37\end{array}$ & 4.807 .939 \\
\hline PIM & $\begin{array}{r}4.997 .4 \\
37 \\
\end{array}$ & 5.572 .877 & $\begin{array}{r}6.840 .55 \\
5 \\
\end{array}$ & $\begin{array}{r}5.572 .8 \\
77 \\
\end{array}$ & $\begin{array}{l}7.896 .41 \\
0\end{array}$ & $\begin{array}{r}8.064 .6 \\
05 \\
\end{array}$ & 7.692 .561 \\
\hline \multicolumn{8}{|l|}{ NON-UREA } \\
\hline SP-36 (Petrokimia & 4.300 .0 & 5.391 .054 & 5.285 .79 & 5.391 .0 & 5.150 .72 & 5.769 .0 & 5.288 .453 \\
\hline
\end{tabular}




\begin{tabular}{|c|c|c|c|c|c|c|c|}
\hline G) & 37 & & 6 & 54 & 8 & 32 & \\
\hline ZA (Petrokimia G) & $\begin{array}{r}2.610 .1 \\
70 \\
\end{array}$ & 3.153 .593 & $\begin{array}{r}3.161 .48 \\
6 \\
\end{array}$ & $\begin{array}{r}3.153 .5 \\
93 \\
\end{array}$ & $\begin{array}{l}3.263 .03 \\
2\end{array}$ & $\begin{array}{r}3.508 .3 \\
35 \\
\end{array}$ & 3.443 .276 \\
\hline \multicolumn{8}{|l|}{ NPK } \\
\hline $\begin{array}{l}\text { - NPK Ponska } \\
\text { (Petrokimia G) }\end{array}$ & $\begin{array}{r}4.951 .5 \\
56 \\
\end{array}$ & 5.939 .566 & $\begin{array}{r}6.299 .23 \\
1 \\
\end{array}$ & $\begin{array}{r}5.939 .5 \\
66 \\
\end{array}$ & $\begin{array}{l}6.299 .23 \\
1 \\
\end{array}$ & $\begin{array}{r}6.247 .0 \\
68 \\
\end{array}$ & 6.632 .776 \\
\hline $\begin{array}{l}\text { - NPK Pelangi } \\
\text { (Pupuk Kaltim) }\end{array}$ & $\begin{array}{r}4.528 .2 \\
59 \\
\end{array}$ & 5.153.562 & $\begin{array}{r}5.631 .29 \\
9 \\
\end{array}$ & $\begin{array}{r}5.153 .5 \\
62 \\
\end{array}$ & $\begin{array}{l}5.631 .29 \\
9 \\
\end{array}$ & $\begin{array}{r}5.814 .3 \\
34 \\
\end{array}$ & 6.905 .233 \\
\hline $\begin{array}{l}\text { - NPK Kujang } \\
\text { (Pupuk Kujang) }\end{array}$ & $\begin{array}{r}4.036 .3 \\
09 \\
\end{array}$ & 4.438 .779 & $\begin{array}{r}5.872 .78 \\
2 \\
\end{array}$ & $\begin{array}{r}4.438 .7 \\
79 \\
\end{array}$ & $\begin{array}{l}5.872 .78 \\
2\end{array}$ & $\begin{array}{r}5.559 .4 \\
32 \\
\end{array}$ & 7.254 .873 \\
\hline \multicolumn{8}{|l|}{ PUPUK ORGANIK } \\
\hline Petrokimia Gresik & $\begin{array}{r}1.752 .9 \\
34\end{array}$ & 1.934 .332 & $\begin{array}{r}1.987 .03 \\
5\end{array}$ & $\begin{array}{r}1.752 .9 \\
34\end{array}$ & $\begin{array}{l}1.847 .73 \\
4\end{array}$ & $\begin{array}{r}1.936 .3 \\
02\end{array}$ & 1.838 .277 \\
\hline Pusri Palembang & $\begin{array}{r}1.809 .3 \\
72 \\
\end{array}$ & 1.583 .353 & $\begin{array}{r}1.971 .04 \\
8 \\
\end{array}$ & $\begin{array}{r}1.809 .3 \\
72 \\
\end{array}$ & $\begin{array}{l}2.072 .45 \\
5\end{array}$ & $\begin{array}{r}1.683 .1 \\
52 \\
\end{array}$ & 2.144 .224 \\
\hline
\end{tabular}

Sumber: KPK

Yang ketiga, adanya gap antara kebutuhan di tingkat petani dan realisasi subsidi oleh Kementerian Pertanian. Dalam hal ini, gap mencakup perbedaan anggaran yang dialokasikan oleh Kementerian Pertanian dan anggaran yang diusulkan oleh Pemerintah Daerah serta penetapan alokasi pupuk di level kabupaten/kota tidak menjangkau sampai level kelompok tani/petani.

Tabel 5. Perbandingan Nilai Pupuk Usulan dan Alokasi Anggaran Pupuk Bersubsidi

\begin{tabular}{|c|c|c|c|}
\hline \multicolumn{2}{|c}{2015} & \multicolumn{3}{c|}{2016} \\
Usulan & Alokasi & Usulan & Alokasi \\
\hline 43.757 .460 .948 .922 & 35.703 .060 .000 .000 & 63.071 .143 .417 .953 & $\begin{array}{c}30.063 .198 .000 . \\
000\end{array}$ \\
\hline
\end{tabular}

Sumber: KPK

Terungkapnya ketiga faktor utama penyebab belum optimalnya kinerja variabel realisasi penyaluran pupuk organik dan anorganik bersubsidi $\left(X_{3}\right)$ dalam model fungsi produksi padi tentu menuntut Pemerintah memperbaiki kebijakan subsidi pupuk agar lebih tepat sasaran dan efisien guna meningkatkan produktivitas dan capaian produksi padi di Indonesia. Peningkatan produktivitas dan capaian produksi padi yang optimal akan berdampak secara langsung dalam ketahanan pangan nasional guna memenuhi kebutuhan konsumsi beras dalam negeri menuju ekonomi Indonesia yang berdikari.

\section{KESIMPULAN}

Penerapan model Cobb-Douglas dalam pemodelan fungsi produksi padi di Indonesia tahun 2016 diselesaikan dengan transformasi Regresi Linier Berganda (RLB) yang menghasilkan model regresi yang fit dan proper. Terbentuk fungsi produksi padi dimana variabel realisasi penyaluran pupuk

organik dan anorganik bersubsidi $\left(\mathrm{X}_{3}\right)$ memiliki nilai elastisitas terendah di antara ketiga variabel independen dan secara statistik tidak signifikan mempengaruhi perubahan nilai produksi padi $(Y)$.

Kinerja variabel realisasi penyaluran pupuk organik dan anorganik bersubsidi $\left(X_{3}\right)$ yang secara statistik tidak signifikan mempengaruhi perubahan nilai produksi padi ( $Y$ ) disebabkan oleh beberapa hal. Yang pertama, adanya keterlambatan penerimaan pupuk bersubsidi di tingkat petani akibat panjangnya mata rantai perencanaan dan penyaluran; kedua, mekanisme penetapan harga penjualan pokok (HPP) pupuk bersubsidi membuka celah korupsi dan mendorong inefisiensi di tingkat produsen; dan ketiga, adanya gap antara kebutuhan di tingkat petani dan realisasi subsidi oleh Kementerian Pertanian. 


\section{DAFTAR PUSTAKA}

BPS. (2016). Ringkasan Eksekutif Luas Panen dan Produksi Beras di Indonesia 2016. Jakarta: Badan Pusat Statistik.

Harianto \& Susila, D. A. B. (2008). Miskin Tetapi Efisien? Suatu Telaah terhadap Fungsi Produksi Padi. Jurnal Agribisnis dan Ekonomi Pertanian, 2(1), 29-38.

Ismayani. (2013). Efisiensi Penggunaan Faktor Produksi Usahatani Kunyit di Kecamatan Lampanah Lengah, Kabupaten Aceh Besar. Agrisep, 14(2), 36-43.

Kementerian Pertanian. (2017). Buletin Data Sarana Pertanian Triwulan IV, Vol. 4 No. 4. Jakarta: Pusat Data dan Sistem Informasi Pertanian.

Kementerian Pertanian. 2017. Pedoman Pelaksanaan Kegiatan Padi 2017. Jakarta: Direktorat Jenderal Tanaman Pangan.

Kementerian Pertanian. (2017). Statistik Ketenagakerjaan Sektor Pertanian Tahun 2016-2017. Jakarta: Pusat Data dan Sistem Informasi Pertanian.

KPK. (2017). Laporan Hasil Kajian Kebijakan Subsidi di Bidang Pertanian. Jakarta: Direktorat Penelitian dan Pengembangan.

Nainggolan, dkk. (2018). Kajian Pendugaan Fungsi Produksi Usahatani Padi Sawah di Kabupaten Muaro Jambi Provinsi Jambi Indonesia. Journal of Agribusiness and Local Wisdom, 1(1).

Rahmawati, dkk. (2018). Usahatani Organik Padi Putih dan Padi Hitam: Pendekatan Pendapatan, Fungsi Produksi Cobb-Douglas dan VPM. Caraka Tani: Journal of Sustainable Agriculture, 33(1), 8-18.

Respikasari, dkk. (2015). Analisis Efisiensi Ekonomi Faktor-Faktor Produksi Usahatani Padi Sawah di Kabupaten Karanganyar. Value Added Majalah Ekonomi dan Bisnis, 11(1). 